\title{
Company Responbility toward Employees Due to Pailit
}

\author{
Masitah Pohan \\ Universitas Muhammadiyah Sumatera Utara, Indonesia \\ masitahpohan@umsu.ac.id
}

\begin{abstract}
Company bankruptcy is a corporate legal phenomenon that is often greatly feared, either by company owners or by its management. Because with company bankruptcy, it means that the company has failed in doing business or at least has failed to pay its debts (debts). The purpose of this research is to identify and analyze the factors of company bankruptcy, the position of employees due to bankruptcy based on Law Number 13 of 2003, due to the legal consequences of bankruptcy against employees based on Law Number 37 of 2004. The research conducted is juridical normative, data sources which is used to support this research is a secondary data source. Factors for the occurrence of company bankruptcy are caused by unpredictable external factors, such as natural disasters. The position of employees due to bankruptcy based on Law Number 13 of 2003 is in Article 95 paragraph (4), clearly and emphasizes that wages and other rights of workers / labor are debts whose payment is prioritized to protect and ensure the survival of their lives and their families. . However, in reality the workers' position is under bankruptcy fees and curator fees, which means that workers must be more patient and stay behind after the bankruptcy of the bankruptcy estate is used to pay taxes, creditors who hold collateral (separatist creditors), bankruptcy fees and curator fees. The legal consequence of the occurrence of bankruptcy for employees based on Law Number 37 Year 2004 is Article 39 paragraph (1) of the Bankruptcy Law.
\end{abstract}

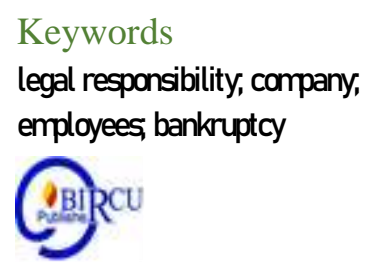

\section{Introduction}

Realizing a society that is prosperous, just, prosperous, evenly distributed, both materially and spiritually based on Pancasila and the 1945 Constitution of the Republic of Indonesia which states that in the implementation of national development, workers have an important role as actors and goals of development. In terms of protection of workers, it is intended to guarantee the basic rights of workers / labor and guarantee equal opportunity and treatment without discrimination on any basis to realize the welfare of workers / laborers and their families while still paying attention to the progress of the business world. One of the articles in the 1945 Constitution, namely Article 28D, which states that everyone has the right to get fair and proper compensation and treatment in a work relationship. ${ }^{1}$

According to Law Number 13 Year 2003 Article 4, manpower development aims to empower and empower the workforce optimally and humanely, create equal employment opportunities, provide protection for workers in realizing welfare and improve the welfare of workers and their families. The law does not specify Termination of Employment (PHK) as the sole result of bankruptcy. Therefore, the bankruptcy decision provides two

\footnotetext{
1 Kompassiana through "/perlindungan-hak-normatif-pekerjaburuh-pada-perusahaan-pailit-457042.html". Accesed on 23 March 2014.
} 
possible alternatives for the Company. First, even though it has been declared bankrupt, the curator of the bankrupt company can continue to carry out its business activities with the consequence that it still pays business costs such as electricity, telephone, wages, taxes and other expenses. Second, the curator of a bankrupt company has the right to terminate the work relationship on the basis of Article 165 of the Manpower Act Number 13 of 2003.

When there are bankruptcy problems and termination of employment within a company, workers / laborers often find it difficult to access information and their rights. In this case, workers' rights and interests of workers are often overlooked by the curator who deals with bankruptcy assets who are more concerned with other creditors and themselves.

There are often disputes between Workers / Laborers and Companies represented by Curators who are more inclined to the rules contained in Law of the Republic of Indonesia Number 37 of 2004 concerning Bankruptcy and Postponement of Debt Payment Obligations and tend to forget the normative rights of workers / laborers as intended. by Manpower Act Number 13 of 2003. ${ }^{2}$ Industrial relations between entrepreneurs and workers / laborers is a system of relations formed between actors in the process of producing goods and / or services consisting of elements from entrepreneurs, workers / laborers and the government based on Pancasila values and the 1945 Constitution of the Republic of Indonesia and Law Number 13 of 2003 concerning Manpower. ${ }^{3}$

Company bankruptcy is a corporate legal phenomenon that is often greatly feared, either by company owners or by its management. Because with company bankruptcy, it means that the company has failed in doing business or at least has failed to pay its debts (debts). A company is declared bankrupt or the popular term is bankruptcy when the company (or an individual) is unable or unwilling to pay its debts. Therefore, the law considers it necessary to regulate this matter, so that debtors' debts can be paid in an orderly manner. ${ }^{4}$

Bankruptcy is intended to prevent separate confiscation or separate execution by creditors and replace it by holding joint confiscations so that the assets of the debtors can be distributed to all creditors in accordance with their respective rights, bankruptcy exists in order to guarantee creditors to obtain their rights over the debtors' assets the bankrupt. ${ }^{5}$

The main problem is the difference in legal and economic positions related to bankruptcy payments between separatist creditors and laborers. For separatist creditors, payments in bankruptcy are guaranteed repayment with a mortgage, collateral, fiduciary, pledge and mortgage. For workers, as special preferred creditors, their position is under the separatist creditors, so that if the debtor's assets have been used as collateral and controlled by the separatist creditors, this can result in the workers not getting anything. Often contrary to the protection of labor rights guaranteed in the 1945 Constitution, namely fair legal certainty and equal treatment because workers as workers have the right to receive compensation and fair and proper treatment from the work they have done which supports their right to life.

Recently, there have been many cases of rights disputes between workers / laborers and curators when clearing bankruptcy assets. Where laborers seem to be sidelined or number two when making payments for Workers / labor rights. The issue of interest is seen from the perspective of workers / laborers whose interests are demanding their unpaid

\footnotetext{
2 Ibid.

3 Ugo dan Pujiyo. 2011. Hukum Acara Penyelesaian Perselisihan Hubungan Industrial. Jakarta: Sinar Grafika, halaman 3.

${ }^{4}$ Munir Fuady. 2005. Pengantar Hukum Bisnis. Bandung: PT. Citra Aditya Bakti, halaman 75.

${ }^{5}$ Imran Nating. 2005. Peranan dan Tanggung Jawab Kurator Dalam Pengurusan dan Pemberesan Harta Pailit. Jakarta: Raja Grafindo Persada, halaman 9.
} 
rights to wages and other rights (normative rights of workers / laborers) but on the other hand there are creditor interests who share the assets of the bankrupt company with a curator as the intermediary. ${ }^{6}$

In fact, the position of the Curator is actually only temporary to replace the position of the company due to bankruptcy. This means that the curator must also act as a company that is obliged to protect and accommodate the rights of workers / labor as mandated by the Manpower Act. Problems like this often happen to workers who, in fact, only rely on their livelihoods from the wages they receive from the job. So this should be the Government's concern on how to respond to the protection of labor rights after the bankruptcy decision and ensure that the interests and rights of workers / labor are protected. ${ }^{7}$

Based on the written background, the main problems in this study are: (1) What are the factors of the company's bankruptcy? (2) What are the legal consequences of bankruptcy for employees based on Law Number 37 Year 2004 concerning Bankruptcy?

\section{Research Methods}

This research is descriptive analytical in which the researcher will describe the legal rule problems related to bankruptcy based on Law Number 37 Year 2004 concerning Bankruptcy. The approach used is an empirical juridical approach, which is an approach that looks from a juridical perspective (applicable regulations or norms) supported by an empirical juridical approach (law enforcement practices that occur in the field).

\section{Results and Discussion}

\subsection{Factors of Company Bankruptcy}

In the business world, a company does not always run well, and often its financial situation is such that the company is no longer able to pay its debts. This can also happen to individuals who carry out a business. It can be said that the life of a company can be in a state of profit or loss. If things are profitable, the company will continue to grow and develop, so that it becomes a giant company. Conversely, if the condition of the company is suffering from a loss, its life line will decrease. So the lifeline of a company at one time increases and at another time decreases, and so on, so that the company's lifeline is a line that goes up and down like a graph. Some of the companies were able to survive, but some of them could no longer survive, and in the end the company was forced to go out of business.

Company bankruptcy / bankruptcy is caused by many factors. These factors can come from external or internal factors. These two factors lead to an imbalance in the company's balance sheet. The internal components of the company consist of human resources, management, organizational structure and means of production. These components are like a mechanical device which is interconnected with one another. The decline in work performance of one of these components affects the other components so that the company's performance is bad.

Competition in a very tight working world exposes organizations to strong efficiency and competitiveness. To improve efficiency, among others required Human Resource (HR) quality. The most important resource in an organization is the human resources, the people

\footnotetext{
${ }^{6}$ Kompassiana melalui "/perlindungan-hak-normatif-pekerjaburuh-pada-perusahaan-pailit-457042.html". diakses pada tanggal 23 Maret 2014

${ }^{7}$ Ibid.
} 
who provide the energy, talents, creativity and their efforts to the organization for an organization to survive its existence (Ningsih, 2018).

Poor company performance in the acute stage makes the company status in the category of bankruptcy. Surely no company in the world expects to be in such a bad position. Because, this means that the losses incurred by the company are enormous. All aspects of the company underwent poor performance. It took a long time to fix it all. ${ }^{8} \mathrm{~A}$ company is said to be bankrupt or the popular term is bankruptcy when the company (or an individual) is unable or unwilling to pay its debts. Therefore, instead of the creditors coming to the debtor and fighting over the debtor's assets, the law considers it necessary to regulate it, so that debtors' debts can be paid in an orderly and fair manner.

Based on this, what is meant by bankruptcy is a general confiscation imposed by a special court, with a special request, on all debtor assets (legal entities or private persons) that have more than one debt in which the debtor stops paying his debts, so that the debtor immediately pay his debts. ${ }^{9}$

Regarding the requirements to be declared bankrupt, Article 2 paragraph (1) of the Law on Bankruptcy and Postponement of Debt Payment Obligations states that a debtor who has 2 or more creditors and does not pay in full at least one debt that is due and can be billed is declared bankrupt with a decision. court, either at its own request or at the request of one or more creditors. Taking into account the above provisions, it can be seen that the requirements for a person to be declared bankrupt through a court decision are:

1. There are at least 2 creditors

2. The debtor does not pay off at least 1 debt.

3. The debt is overdue and is collectible.

Company bankruptcy caused by external factors can still be overcome by the company. Unpredictable external factors, such as natural disasters. Damage to company performance only occurs in the physical company. The damage is guaranteed by the government or insurance financial institution. The production sector has only stopped temporarily while the financial sector is still guaranteed. The decline in company work performance is only temporary.

Companies can also go bankrupt because shareholders leave. When the shareholders (Stake Holders) leave, it will cause bankruptcy in a company, because a shareholder has a very important role in the running of a company. Shareholders or stake holders are people who invest in a company that is managed to get certain benefits. If a shareholder leaves and withdraws his shares, a company will not run strongly, due to a lack of capital to supply goods or equipment needed by a company. The more shareholders who leave or withdraw their capital, the greater the chance for the company to go bankrupt. ${ }^{10}$

\subsection{The Legal Consequences of the Bankruptcy of Employees Based on Law Number 37 of 2004 concerning Bankruptcy \\ Most labor laws are imperative, which have the following functions and objectives in labor law: \\ 1. To achieve and implement social justice in the manpower sector.}

\footnotetext{
8 Cimumuci melalui "http://cimumuci.blogspot.com/2012/05/perusahaan-yang-telah-pailit.html”, diakses pada tanggal 4 Agustus 2014.

9 Welcome melalui "http://skullcmeira.blogspot.com/2011/10/kepailitan.html", diakses pada tanggal 4 Agustus 2014.

${ }^{10}$ Zulyadaini melalui "http://zulyadai.wordpress.com/2012/06/19/penyebab-perusahaan-pailit/", diakses pada tanggal 4 Agustus 2014.
} 
2. To protect workers against the unlimited power of entrepreneurs, for example by making or creating regulations that are forcing so that employers do not act arbitrarily against workers as the weak party.

A bankruptcy decision has legal consequences or implications for the assets of the debtor as well as for the bankrupt debtor itself, such as managing the assets that have passed into the hands of the curator or even the right to take any legal remedies that affect the assets of the debtor must be carried out by the curator. In general, there are several main consequences of bankruptcy law, which include:

1. The decision to bankruptcy is immediate

The decision to declare bankruptcy by the commercial court (first level) is an immediate decision (can be implemented first or uitvoorbaar bij voorraad) even though the decision is still being filed for cassation. Thus, the curator was already working when the bankruptcy verdict fell, despite the legal remedies. If the bankruptcy decision is overturned at the cassation level, all actions of the curator prior to the discovery of the cassation decision are still considered valid and binding. This is regulated in Article 16 paragraph (2) of Law Number 37 of 2004. In addition to the decision of the Commercial Court regarding the immediate bankruptcy and other decisions of the commercial court regarding bankruptcy, the Supervisory Judge's decision is also automatic, except other determined by Law Number 37 Year 2004 regarding bankruptcy.

2. Losing the right to control

There are several juridical consequences after the bankruptcy statement is declared or after the bankruptcy statement is declared legally binding, or after the bankruptcy ends. In cases like this, the commercial court, supervisory judge, curator, creditors and anyone involved in the bankruptcy process cannot contribute directly to the juridical consequences. Basically, the legal consequence of bankruptcy is for the sake of the law the loss of the right to control and manage one's assets and is included in the bankruptcy estate, since the decision to declare bankruptcy is pronounced. In view of the provisions of the Bankruptcy Law, particularly in Article 21, which states that "bankruptcy includes all assets of the debtor at the time the decision to declare bankruptcy is pronounced as well as everything obtained during the bankruptcy". ${ }^{11}$

3. Inggris

General confiscation applies to all assets of the debtor In principle, bankruptcy against a debtor means placing general confiscation of all the debtor's assets. Because other confiscations, if any, must be considered null and void because of the law. The general confiscation applies to the entire assets of the debtor, including:

a) Assets existing at the time of the bankruptcy declaration.

b) Assets acquired by the debtor during the bankruptcy.

The essence of the general confiscation of the debtor's assets is that the purpose of the bankruptcy is to stop the action against the seizure of the bankruptcy by the creditors and to stop the traffic of transactions of the bankruptcy property by the debtor which is likely to harm the creditors. With this general confiscation, the bankruptcy assets are in the status of terminated from all kinds of transactions and other legal actions until the bankruptcy assets are taken care of by the curator.

\footnotetext{
${ }^{11}$ Danang Suyato. 2013. Hak Dan Kewajiaban bagi Pekerja Dan Pengusaha. Jakarta: Buku Seru, halaman 14.
} 


\section{Bankruptcy assets can be sealed}

A harat has been sealed, so if the bankrupt debtor dares to break the seal of the asset, then the act is considered a criminal act. So based on these considerations, the sealing of bankruptcy assets can be carried out with the approval of the supervisory judge. The sealing is carried out by the substitute clerk at the place where the assets are in the presence of two witnesses, one of whom is a representative of the local government, this is based on Article 99 of Law Number 34 Year 2004 concerning Bankruptcy and postponement of debt payments. Based on the sealing context of bankruptcy assets, Fuady stated that for certain legal consequences of bankruptcy, a rule of reason applies. The point is that the legal consequences do not automatically apply, but only if it is enforced by certain parties after having a reasonable reason to enforce it. For example, a bankruptcy effect requiring a rule of reason is the sealing of bankruptcy assets. In this case, the assets of the bankrupt debtor can be sealed with the approval of the supervisory judge, so it does not happen automatically. The reason for sealing the bankruptcy estate is to secure the bankruptcy estate itself.

Basically, an entrepreneur has the responsibility to fulfill the rights of workers / laborers. An entrepreneur is not only responsible for the rights of his workers / laborers but has an obligation to fulfill the rights of workers / labor. This is because the relationship between the worker / laborer and the entrepreneur arises because of the existence of a work agreement in which the parties have agreed on the rights and obligations as well as the conditions of work between the worker / laborer and the entrepreneur. Workers / laborers have given their energy and thoughts to get profits for the company and when the company suffers a loss, the worker / laborer will continue to assume their rights as workers / laborers. Based on Article 39 paragraph (1) of the Bankruptcy Law, there are two possibilities for the fate of workers / laborers if the company is declared bankrupt, namely:

1. Workers / laborers can terminate employment relations, so it can be concluded from the provisions of Article 39 paragraph (1) of the Bankruptcy Law that the consequence of workers in a company that is considered bankrupt is termination of employment. Termination of employment is at least 45 days after notification of termination of employment.

2. Entrepreneurs whose authority has been transferred to the curator may terminate workers / laborers.

The position of the worker / laborer and the entrepreneur is a relationship between superiors and subordinates (subordinate). When talking about the position in the work relationship, it is also necessary to explain the nature of the work relationship both juridically, sociologically and socio-economically. The juridical essence of the relationship between workers / labor and entrepreneurs is a free relationship because each party can agree on the rights and obligations as well as the terms of work in a work agreement. This is based on the principle of freedom of contract. As a party who feels aggrieved in an agreement, workers / laborers can sue the company demanding that the workers / laborers' rights be fulfilled immediately. However, under the Bankruptcy Law, the rights of workers / laborers to sue are null and void after the bankruptcy decision. Even though the lawsuit was already in trial, the process was canceled due to the bankruptcy decision. Based on Article 29 of the Bankruptcy Law, a lawsuit filed against the debtor to the extent that it aims to obtain fulfillment of the obligations of the bankruptcy property and the case is ongoing, is null and void by pronouncing the declaration of bankruptcy against the debtor.

The claim has been granted and the debtor is ordered by the court to pay his debt, so the court's decision cannot be implemented after the bankruptcy decision. Based on Article 26 paragraph (2) of the Bankruptcy Law, claims regarding rights or obligations relating to bankruptcy assets result in a punishment for the Bankrupt Debtor, so the sentence will not 
have legal consequences for the bankruptcy property. Therefore, even though the court prior to the bankruptcy decision had determined that the company had to pay the workers' wages, with the bankruptcy decision the court decision was null and void. With the provisions contained in Article 26 paragraph (2) and Article 29 of the Bankruptcy Law, workers / laborers have no other choice to obtain their rights except to participate as bankrupt creditors, and if the debt value is greater than the bankruptcy assets, it is likely that the workers / laborers will not get all the rights.

\section{Conclusion}

The factor of the company's bankruptcy is caused by unpredictable external factors, such as natural disasters. Damage to company performance only occurs in the physical company. The damage is guaranteed by the government or insurance financial institution. And the company's internal factors, which are related to the company's balance sheet and the company's organizational structure. The company went bankrupt due to internal company errors forcing the company's managerial and structural ranks to undergo a reshuffle. Companies can also go bankrupt because shareholders leave.

The legal consequence of the occurrence of bankruptcy against employees based on Law Number 37 Year 2004 is that in Article 39 paragraph (1) of the Bankruptcy Law, there are two possibilities for the fate of workers / laborers if the company is declared bankrupt, namely: Employers whose authority has been transferred to The curator can terminate the worker / laborer and the worker / laborer can terminate the employment relationship, so that it can be concluded from the provisions of Article 39 paragraph (1) of the Bankruptcy Law that the consequence / consequence of workers / labor in a company that is considered bankrupt is termination of employment.

\section{References}

Danang Suyato. 2013. Hak Dan Kewajiaban bagi Pekerja Dan Pengusaha. Jakarta: Buku Seru.

Edward Manik. 2012. Cara Mudah Memahami Proses Kepailitan Dan Penundaan Kewajiban Pembayaran Utang. Bandung: Mandar Maju.

Imran Nating, S.H., M.H. 2005. Peranan dan Tanggung Jawab Kurator Dalam Pengurusan dan Pemberesan Harta Pailit. Jakarta: Raja Grafindo Persada.

Kitab Undang-Undang Hukum Perdata

Kompassiana melalui “/perlindungan-hak-normatif-pekerjaburuh-pada-perusahaan-pailit457042.html”. diakses pada tanggal 23 Maret 2014.

Munir Fuady. 2005. Pengantar Hukum Bisnis. Bandung: PT. Citra Aditya Bakti.

Ningsih, S. (2018). The Relationship Between Motivation and Worker's Productivity in Civil Registration and Population Department, Asahan Regency, Indonesia. Budapest International Research and Critics Institute-Journal (BIRCI-Journal). P. 148-160.

Ugo dan Pujiyo. 2011. Hukum Acara Penyelesaian Perselisihan Hubungan Industrial. Jakarta: Sinar Grafika.

Undang-Undang Nomor 13 tahun 2003 tentang Ketenagakerjaan

Undang-Undang Nomor 37 tahun 2004 tentang Kepailitan dan Penundaan Pembayaran Hutang

Susilo Andi Darma. 2013. Kedudukan Pekerja/Buruh dalam Perkara Kepailitan Ditinjau dari Peraturan Perundang-Undangan dan Teori Keadilan. Jurnal. Fakultas Hukum Universitas Gajah Mada (UGM) Yogyakarta. 